Article

\title{
Antioxidant and Cytoprotective Properties of Cyanobacteria: Potential for Biotechnological Applications
}

\author{
Adriana Guerreiro ${ }^{1,2}$, Mariana A. Andrade ${ }^{3}$, Carina Menezes ${ }^{1,4}$, Fernanda Vilarinho ${ }^{3}(\mathbb{D}$ and \\ Elsa Dias $1,5, *$ (D) \\ 1 Laboratory of Biology and Ecotoxicology, Department Environmental Health, \\ National Institute of Health Dr. Ricardo Jorge, Avenida Padre Cruz, 1649-016 Lisboa, Portugal; \\ adriana.guerreiro@insa.min-saude.pt (A.G.); carina.menezes@insa.min-saude.pt (C.M.) \\ 2 Faculty of Sciences, University of Lisbon, Campo Grande, 1749-016 Lisboa, Portugal \\ 3 Laboratory of Chemisty, Department Food and Nutrition, National Institute of Health Dr. Ricardo Jorge, \\ Avenida Padre Cruz, 1649-016 Lisboa, Portugal; mariana.andrade@insa.min-saude.pt (M.A.A.); \\ fernanda.vilarinho@insa.min-saude.pt (F.V.) \\ 4 Instituto Superior Técnico, University of Lisbon, Av. Rovisco Pais, 1, 1049-001 Lisboa, Portugal \\ 5 Centro de Estudos de Ciência Animal (CECA/ICETA), University of Porto, Rua D. Manuel II, \\ Apartado 55412, 4051-401 Porto, Portugal \\ * Correspondence: elsa.dias@insa.min-saude.pt; Tel.: +351-217519200
}

Received: 12 June 2020; Accepted: 7 August 2020; Published: 26 August 2020

check for updates

\begin{abstract}
Antioxidant compounds from cyanobacteria may constitute a natural alternative to current synthetic antioxidants, which contain preservatives and suspected toxicity. In this work, we evaluate the antioxidant potential of cyanobacterial strains of distinct species/genus isolated from freshwater $(n=6)$, soil $(n=1)$ and wastewater $(n=1)$ environments. Lyophilized biomass obtained from in-vitro cultures of those strains was extracted with ethanol and methanol. The antioxidant potential was evaluated by chemical (DPPH scavenging method, $\beta$-carotene bleaching assay, determination of total phenolic and total flavonoid compounds) and biological $\left(\mathrm{H}_{2} \mathrm{O}_{2}\right.$-exposed HEK293T cell line model) approach. Some strains showed high yields of antioxidant activity by the DPPH assay (up to $10.7 \% \mathrm{IP} / 20.7 \mathrm{TE} \mu \mathrm{g} / \mathrm{mL}$ ) and by the $\beta$-carotene bleaching assay (up to $828.94 \mathrm{AAC}$ ), as well as significant content in phenolic (123.16 mg EAG/g DW) and flavonoid (900.60 mg EQR/g DW) compounds. Normalization of data in a "per cell" or "per cell volume" base might facilitate the comparison between strains. Additionally, most of the cyanobacterial extracts conferred some degree of protection to HEK293T cells against the $\mathrm{H}_{2} \mathrm{O}_{2}$-induced cytotoxicity. Freshwater Aphanizomenon gracile (LMECYA 009) and Aphanizomenon flos-aquae (LMECYA 088), terrestrial Nostoc (LMECYA 291) and wastewater Planktothrix mougeotii (LEGE 06224) seem to be promising strains for further investigation on cyanobacteria antioxidant potential.
\end{abstract}

Keywords: cyanobacteria; antioxidant potential; natural antioxidants; DPPH assay; $\beta$-carotene bleaching assay; phenolic; flavonoids; HEK293T cell line; cytotoxicity prevention

Key Contribution: This study demonstrates the antioxidant potential of several cyanobacterial strains isolated from water and terrestrial environments. The access to a collection of cyanobacterial isolates will allow for the exploitation of these properties in numerous strains of varied species occurring in national natural resources. These results emphasize the importance of cyanobacteria as natural sources of antioxidant compounds with potential biotechnological applications. 


\section{Introduction}

Cyanobacteria are a diverse group of photosynthetic prokaryotes, with an estimated number of 8000 species distributed by 150 genera, that, in turn, colonize a variety of aquatic and terrestrial environments, from temperate to tropical and polar regions worldwide [1,2]. Along their evolutionary path, cyanobacteria have developed a multitude of strategies enabling them to adapt and survive in such distinct environments. For example, many cyanobacterial species are predominant in habitats exposed to high solar irradiance and, consequently, developed several mechanisms to protect themselves against the noxious effects of UV light [3]. One of those mechanisms is the production of primary sunscreens such as the pigment Scytonemin or the mycosporine-like amino acids (MAAs) that absorb harmful radiation [3,4]. Besides, MAAs can also act as radical scavengers and protect cyanobacteria from UV-induced oxidative stress [4]. On the other hand, cyanobacteria are an important oxygen source and, as such, must defend themselves against their own induced oxidative environment. Consequently, cyanobacteria produce a variety of secondary metabolites that are effective against reactive oxygen species (ROS), particularly pigments such as carotenoids, as well as polyphenols such as phenolic acids and flavonoid compounds [5-7].

Cyanobacteria are a source of bioactive substances with many potential biotechnological applications and their antioxidant compounds, particularly, have been considered promising molecules for the cosmetics [8] and food [9] industries. Indeed, the search for natural antioxidant compounds has gained increasing interest, considering current synthetic antioxidant compounds contain preservatives and suspected toxicity [10]. The marine environment has been a privileged niche for the research of bioactive compounds in cyanobacteria [11]. However, we can currently find in the literature a huge diversity of publications on the antioxidant activity of cyanobacteria from freshwater and terrestrial habitats [5-7,9,12-18]. In general, these studies point to an interest in exploring the antioxidant activity of cyanobacteria, considering their richness of compounds such as carotenoids and polyphenols. Inclusively, some of these authors reported antioxidant activity $[5,13,16,17,19,20]$ and/or antioxidant contents $[11,14,15,21]$ in cyanobacteria quite comparable, and sometimes higher, than those found in eukaryotic microalgae, macroalgae or higher plants [22-25].

The present work aimed to evaluate the antioxidant potential of several cyanobacteria species isolated from freshwater, wastewater and soil. To achieve that purpose, we used both chemical (DPPH inhibition assay, $\beta$-carotene bleaching assay, determination of total phenolic and flavonoid compounds) and biological (evaluation of the protective effect of cyanobacterial extracts against $\mathrm{H}_{2} \mathrm{O}_{2}$-induced cytotoxicity in HEK293T cell line) approaches.

\section{Results}

\subsection{Antioxidant Profile of Cyanobacterial Strains}

The results of the DPPH inhibition assay, expressed as the inhibition percentage or as Trolox equivalents (TE), are presented in Figure 1. The methanolic extracts exhibited higher values of antioxidant capacity than the ethanolic extracts, irrespectively of the cyanobacterial strain. The exception was Planktothrix mougeotii (LEGE 06224), which showed similar values of antioxidant activity with the two extraction solvents. The methanolic extracts with the highest antioxidant activity were obtained from Microcystis aeruginosa (LMECYA 127), Dolichospermum flos-aquae (LMECYA 180), Planktothrix agardhii (LMECYA 257) and Planktothrix mougeotii (LEGE 06224). In those extracts, the DPPH inhibition percentage varied between $8.8 \%$ and $10.7 \%$, corresponding to $17.3 \mathrm{TE} \mu \mathrm{g} / \mathrm{mL}$ to $20.7 \mathrm{TE} \mu \mathrm{g} / \mathrm{mL}$. 

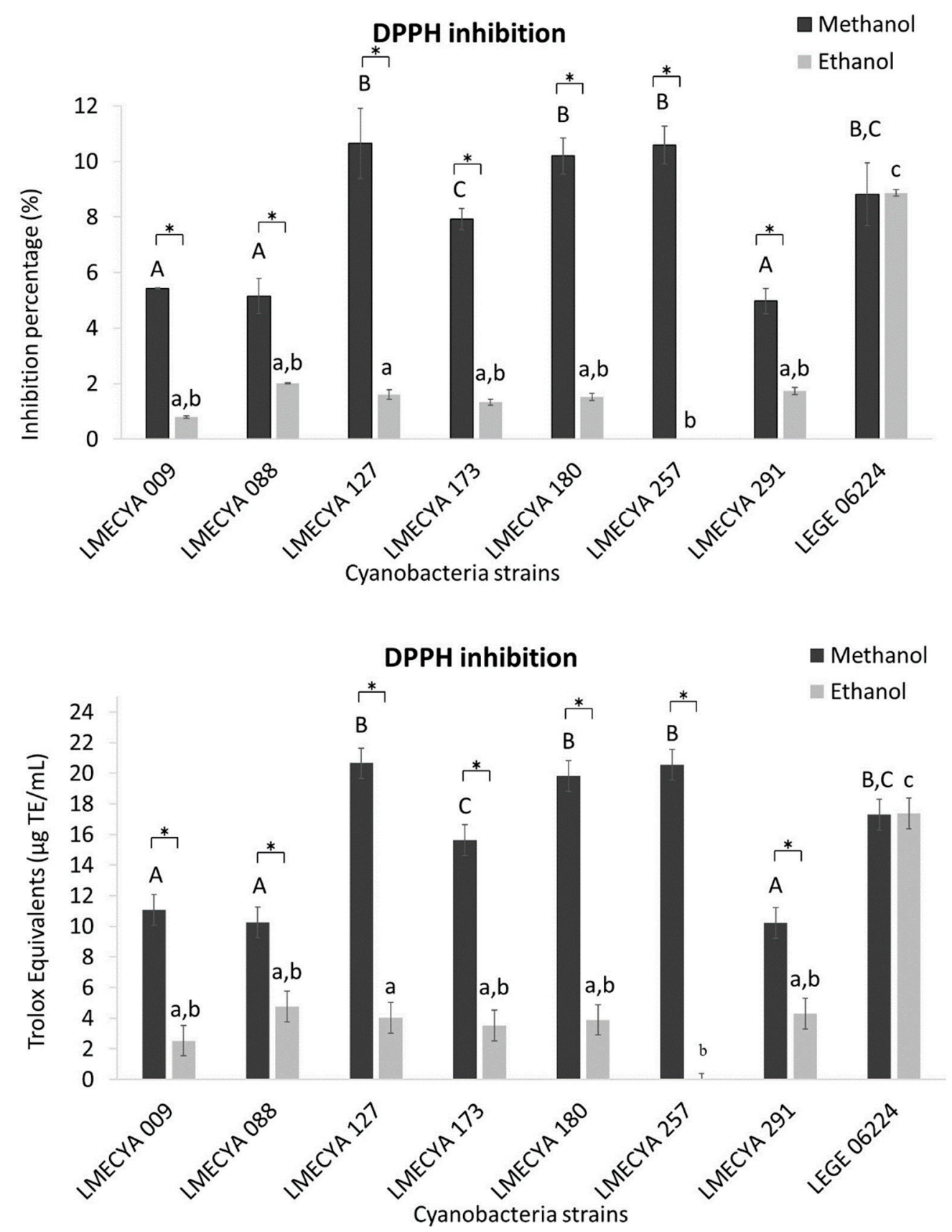

Figure 1. Antioxidant activity of methanolic and ethanolic cyanobacterial extracts $(1 \mathrm{mg} \mathrm{DW} / \mathrm{mL})$ evaluated by the DPPH inhibition assay and expressed as Inhibition percentage (upper graph) and Trolox equivalents (lower graph). Cyanobacterial strains: Aphanizomenon gracile (LMECYA 009), Aphanizomenon flos-aquae (LMECYA 088), Microcystis aeruginosa (LMECYA 127), Leptolyngbya sp. (LMECYA 173), Dolichospermum flos-aquae (LMECYA 180), Planktothrix agardhii (LMECYA 257), Nostoc sp. (LMECYA 291), Planktothrix mougeotii (LEGE 06224). * represents a statistically significant difference $(p<0.05)$ between methanolic and ethanolic extracts of each cyanobacterial strain. Different lower-case letters represent significant statistic differences $(p<0.05)$ between the ethanolic extracts of the eight cyanobacteria strains. Different capital letters represent significant statistic differences $(p<0.05)$ between the methanolic extracts of the eight cyanobacteria strains.

The results for the $\beta$-carotene bleaching test are shown in Figure 2 . In this case, the ethanolic extracts showed higher antioxidant activity than the methanolic extracts in most of the cyanobacterial strains. Aphanizomenon flos-aquae (LMECYA 088) and Aphanizomenon gracile (LMECYA 009) exhibited 
the highest values of antioxidant activity coefficient (AAC) (825.9 and 690.5 AAC, respectively), followed by Dolichospermum flos-aquae (LMECYA 180) (384 AAC). On the contrary, methanolic extract of Microcystis aeruginosa (LMECYA 127) showed considerably higher activity (456.2 AAC) than the ethanolic extract of the same strain (79.4 AAC). In the remaining strains, the differences between the solvents were not so pronounced.

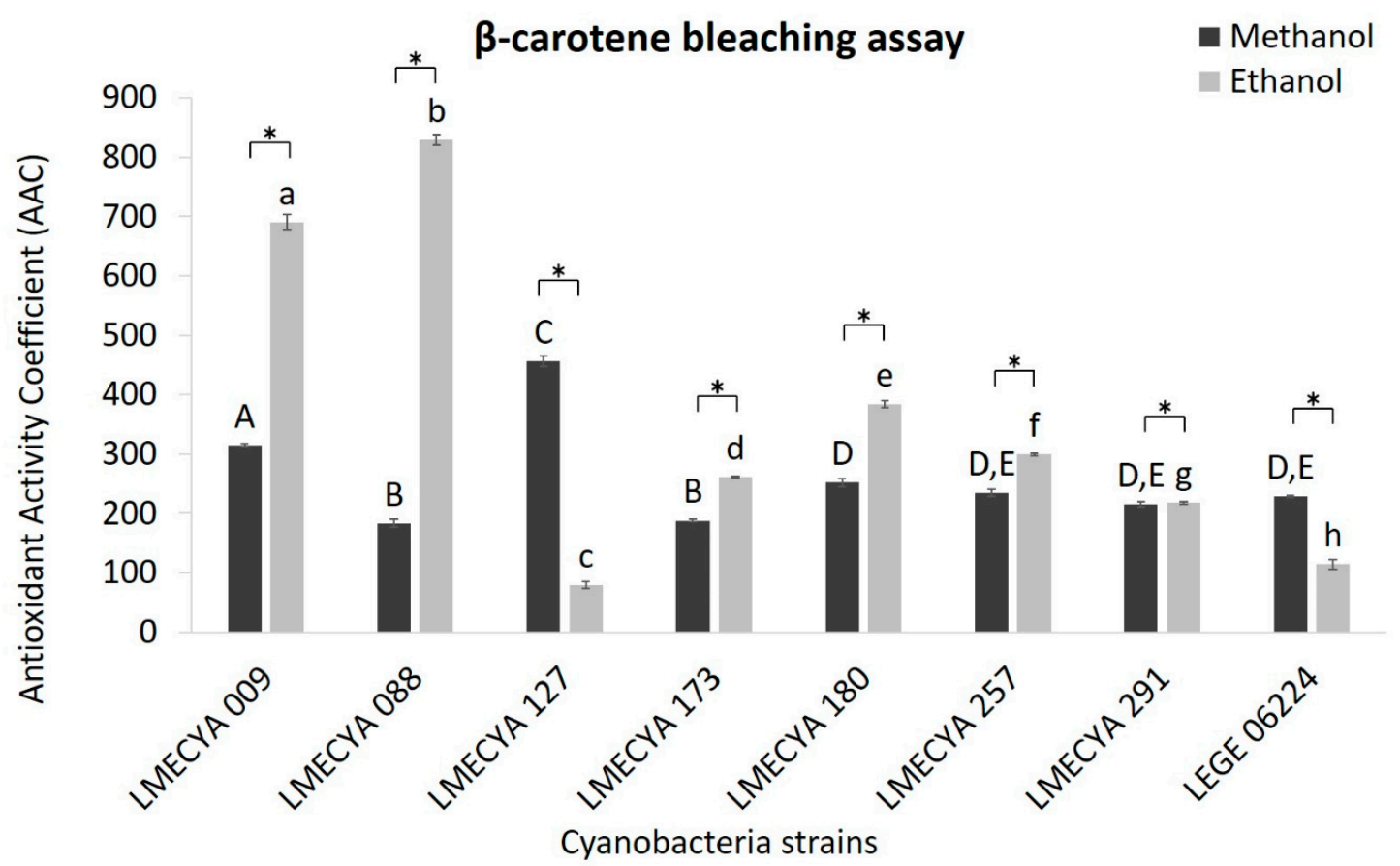

Figure 2. Antioxidant activity coefficient (AAC) of methanolic and ethanolic cyanobacterial extracts (1mg DW/mL) evaluated by the $\beta$-carotene bleaching assay. Cyanobacterial strains: Aphanizomenon gracile (LMECYA 009), Aphanizomenon flos-aquae (LMECYA 088), Microcystis aeruginosa (LMECYA 127), Leptolyngbya sp. (LMECYA 173), Dolichospermum flos-aquae (LMECYA 180), Planktothrix agardhii (LMECYA 257), Nostoc sp. (LMECYA 291), Planktothrix mougeotii (LEGE 06224). * represents a statistically significant difference $(p<0.05)$ between methanolic and ethanolic extracts of each cyanobacterial strain. Different lower-case letters represent significant statistic differences $(p<0.05)$ between the ethanolic extracts of the eight cyanobacteria strains. Different capital letters represent significant statistic differences $(p<0.05)$ between the methanolic extracts of the eight cyanobacteria strains.

The content of total phenolic compounds was also higher in the majority of the ethanolic extracts (Figure 3). In those extracts, the highest phenolic concentrations (expressed as Galic Acid Equivalents, GAE) were observed in Aphanizomenon flos-aquae LMECYA 088 (123.2 mg GAE/g DW), Aphanizomenon gracile LMECYA 009 (102.3 mg GAE/g DW), Dolichospermum flos-aquae LMECYA 180 (63.7 mg GAE/g DW) and Planktothrix mougeotii LEGE 06224 (61.1 mg GAE/g DW). As for the previous assay, the higher content of phenolic compounds in Microcystis aeruginosa LMECYA 127 (67.1 mg GAE/g DW) was detected in the methanolic extract, a similar value to that obtained with methanolic extract of Aphanizomenon gracile LMECYA 009 (68.1 mg GAE/g DW). The remaining strains had lower results with both solvents.

As for the previous assays, the content of total flavonoids (Figure 4) was higher in the ethanolic extracts of Aphanizomenon gracile (LMECYA 009) and Aphanizomenon flos-aquae (LMECYA 088 ) (606 and $901 \mathrm{mg}$ Quercitine Equivalents-QE/g DW, respectively). The remaining strains showed slightly higher results in extracts prepared with methanol, but the concentration of flavonoids was considerably lower than in the extracts of those two Apanizomenon strains. 


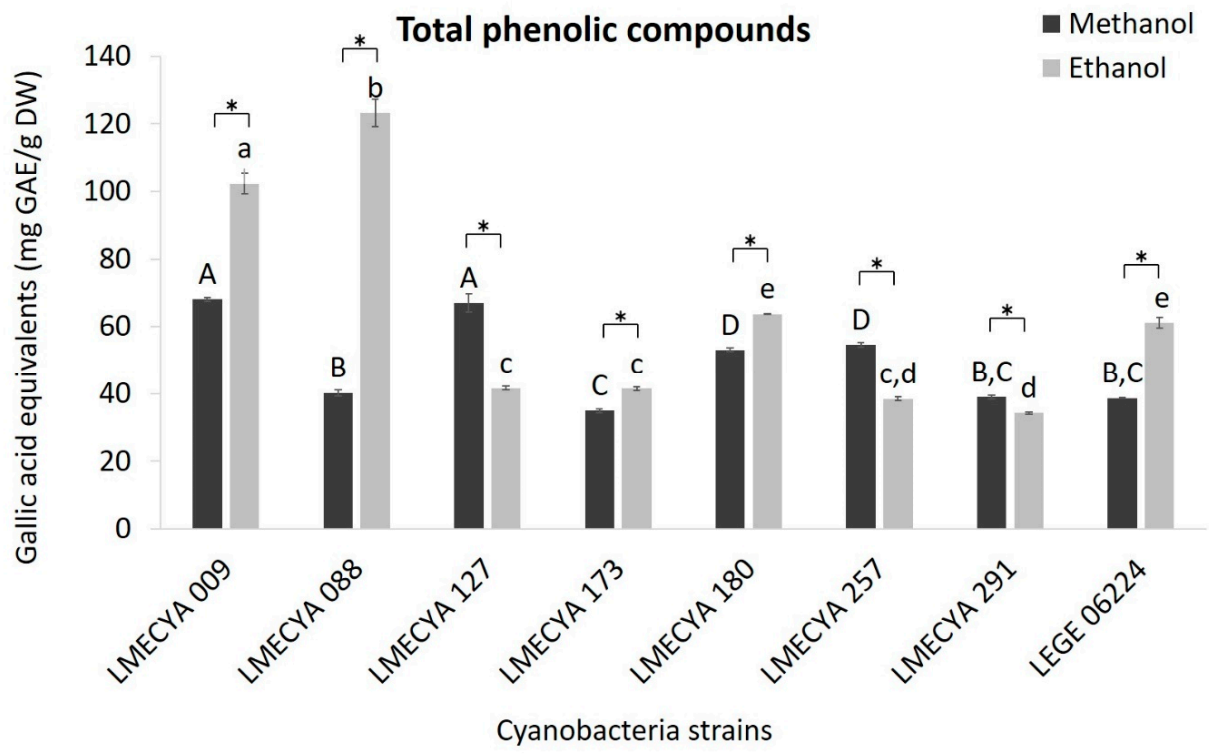

Figure 3. Total phenolic content (mg GAE/g DW) of methanolic and ethanolic cyanobacterial extracts (1 mg DW/mL). Cyanobacterial strains: Aphanizomenon gracile (LMECYA 009), Aphanizomenon flos-aquae (LMECYA 088), Microcystis aeruginosa (LMECYA 127), Leptolyngbya sp. (LMECYA 173), Dolichospermum flos-aquae (LMECYA 180), Planktothrix agardhii (LMECYA 257), Nostoc sp. (LMECYA 291), Planktothrix mougeotii (LEGE 06224). * represents a statistically significant difference $(p<0.05)$ between methanolic and ethanolic extracts of each cyanobacterial strain. Different lower-case letters represent significant statistic differences $(p<0.05)$ between the ethanolic extracts of the eight cyanobacteria strains. Different capital letters represent significant statistic differences $(p<0.05)$ between the methanolic extracts of the eight cyanobacteria strains.

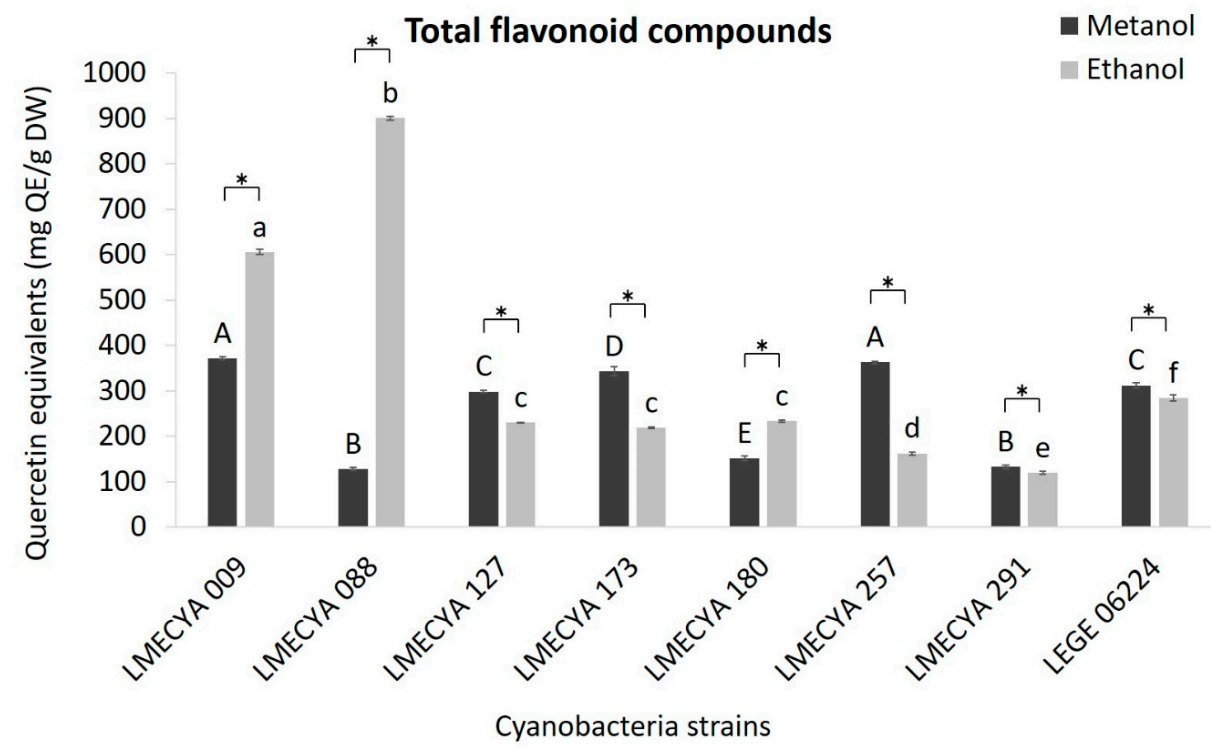

Figure 4. Total flavonoid content (mg QE/g DW) of methanolic and ethanolic cyanobacterial extracts (1 mg DW/mL). Cyanobacterial strains: Aphanizomenon gracile (LMECYA 009), Aphanizomenon flos-aquae (LMECYA 088), Microcystis aeruginosa (LMECYA 127), Leptolyngbya sp. (LMECYA 173), Dolichospermum flos-aquae (LMECYA 180), Planktothrix agardhii (LMECYA 257), Nostoc sp. (LMECYA 291), Planktothrix mougeotii (LEGE 06224). * represents a statistically significant difference $(p<0.05)$ between methanolic and ethanolic extracts of each cyanobacterial strain. Different lower-case letters represent significant statistic differences $(p<0.05)$ between the ethanolic extracts of the eight cyanobacteria strains. Different capital letters represent significant statistic differences $(p<0.05)$ between the methanolic extracts of the eight cyanobacteria strains. 
To refine the comparison between cyanobacterial strains, the antioxidant content per cell and per cell volume $\left(\mu^{3}\right)$ for each strain was determined (Figure 5 and Table S1). Nostoc sp. (LMECYA 291) was the strain with the highest antioxidant content, irrespectively of the antioxidant endpoint. As shown in Figure 5, the antioxidant content per cell (or per cell volume) in this strain was one to three orders of magnitude higher than other strains. Planktothrix mougeotii (LEGE 06224), Microcystis aeruginosa (LMECYA 127), Dolichospermum flos-aquae (LMECYA 180) and Planktothrix agardhii (LMECYA 257) followed as the strains with higher antioxidant content per cell.
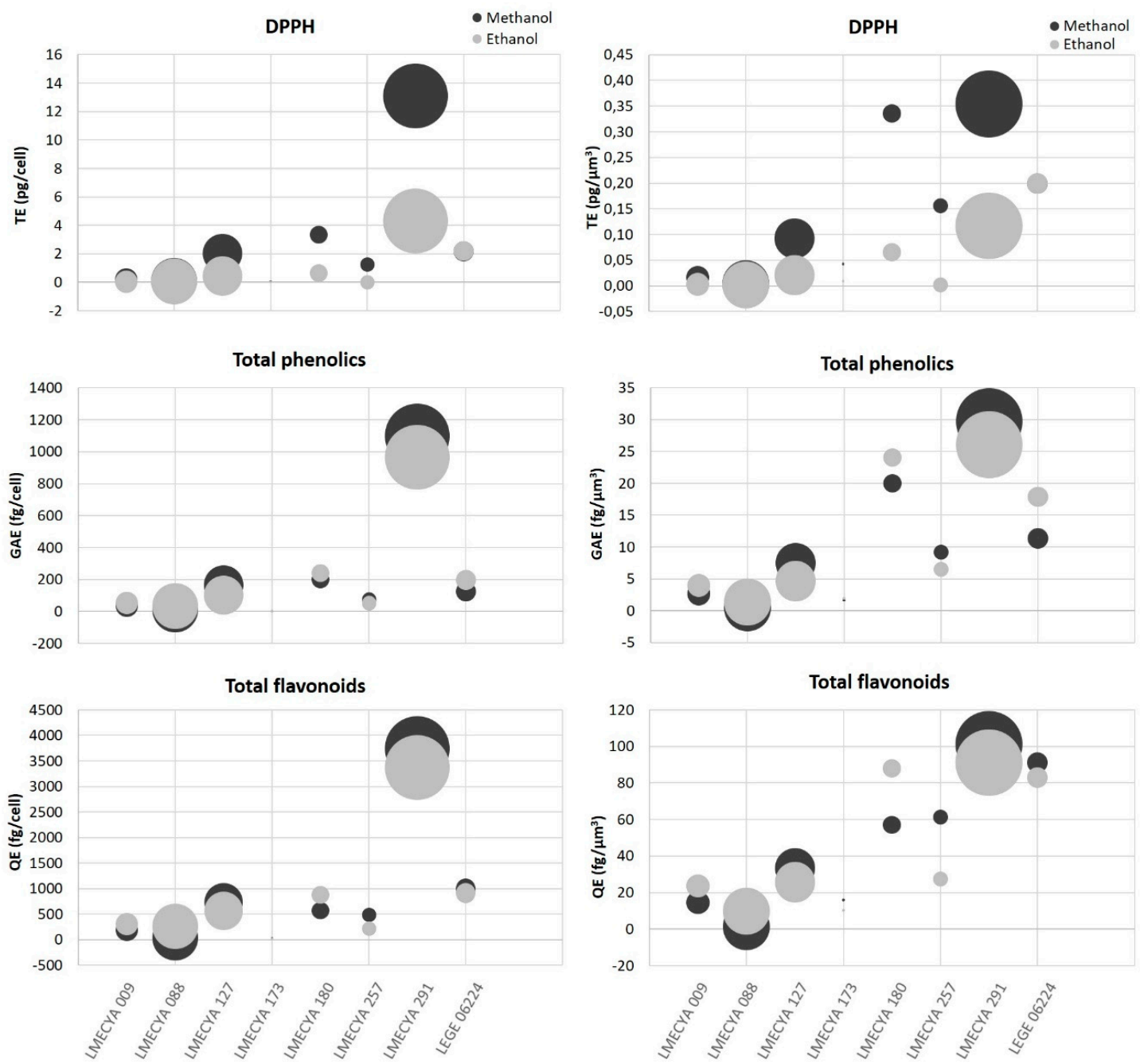

Figure 5. Antioxidant content (DPPH, total phenolic and total flavonoid compounds) of methanolic and ethanolic cyanobacterial extracts per cell (left) or per cell volume $\left(\mu \mathrm{m}^{3}\right)$ (right). Cyanobacterial strains: Aphanizomenon gracile (LMECYA 009), Aphanizomenon flos-aquae (LMECYA 088), Microcystis aeruginosa (LMECYA 127), Leptolyngbya sp. (LMECYA 173), Dolichospermum flos-aquae (LMECYA 180), Planktothrix agardhii (LMECYA 257), Nostoc sp. (LMECYA 291), Planktothrix mougeotii (LEGE 06224).

\subsection{Protective Effect of Cyanobacterial Extracts on HEK293T Cell Line against $\mathrm{H}_{2} \mathrm{O}_{2}$-Induced Cytotoxicity}

Figure 6 shows the viability of HEK293T cells exposed to a short period $(1 \mathrm{~h})$ to cyanobacterial ethanolic extracts followed by a long exposure period $(23 \mathrm{~h})$ to $\mathrm{H}_{2} \mathrm{O}_{2}(0.1 \mathrm{mM})$. Data shows that there are no significant differences between the viability of cells exposed to cyanobacterial extracts and $\mathrm{H}_{2} \mathrm{O}_{2}$ (with or without an extract washing step before adding $\mathrm{H}_{2} \mathrm{O}_{2}$ ) and cells exposed only to the cyanobacterial extracts, for the majority of the strains. It seems, thus, that the extracts somehow reverse the cytotoxic effect of $\mathrm{H}_{2} \mathrm{O}_{2}$. Exception was LMECYA 009 and LMECYA 088, where the viability of 
cells exposed to $\mathrm{H}_{2} \mathrm{O}_{2}$ after removing the cyanobacterial extracts (Figure 6, top) was lower than the cells co-incubated with extracts and $\mathrm{H}_{2} \mathrm{O}_{2}$ or incubated only with extracts. Even though, the cell viability was higher in cells pre-treated with cyanobacterial extracts when compared with the positive controls (see Material and Methods, item 5.5.1). Indeed, except for LMECYA 009 and LMECYA 291, all the extracts induced cell survival with survival percentages between $7 \%$ and 52\% (Figure 6, bottom). These were higher when the cyanobacterial extract was washed prior to $\mathrm{H}_{2} \mathrm{O}_{2}$ exposure.

$$
\text { 1h Extract }+23 \mathrm{~h} \mathrm{H}_{2} \mathrm{O}_{2}(0.1 \mathrm{mM})
$$
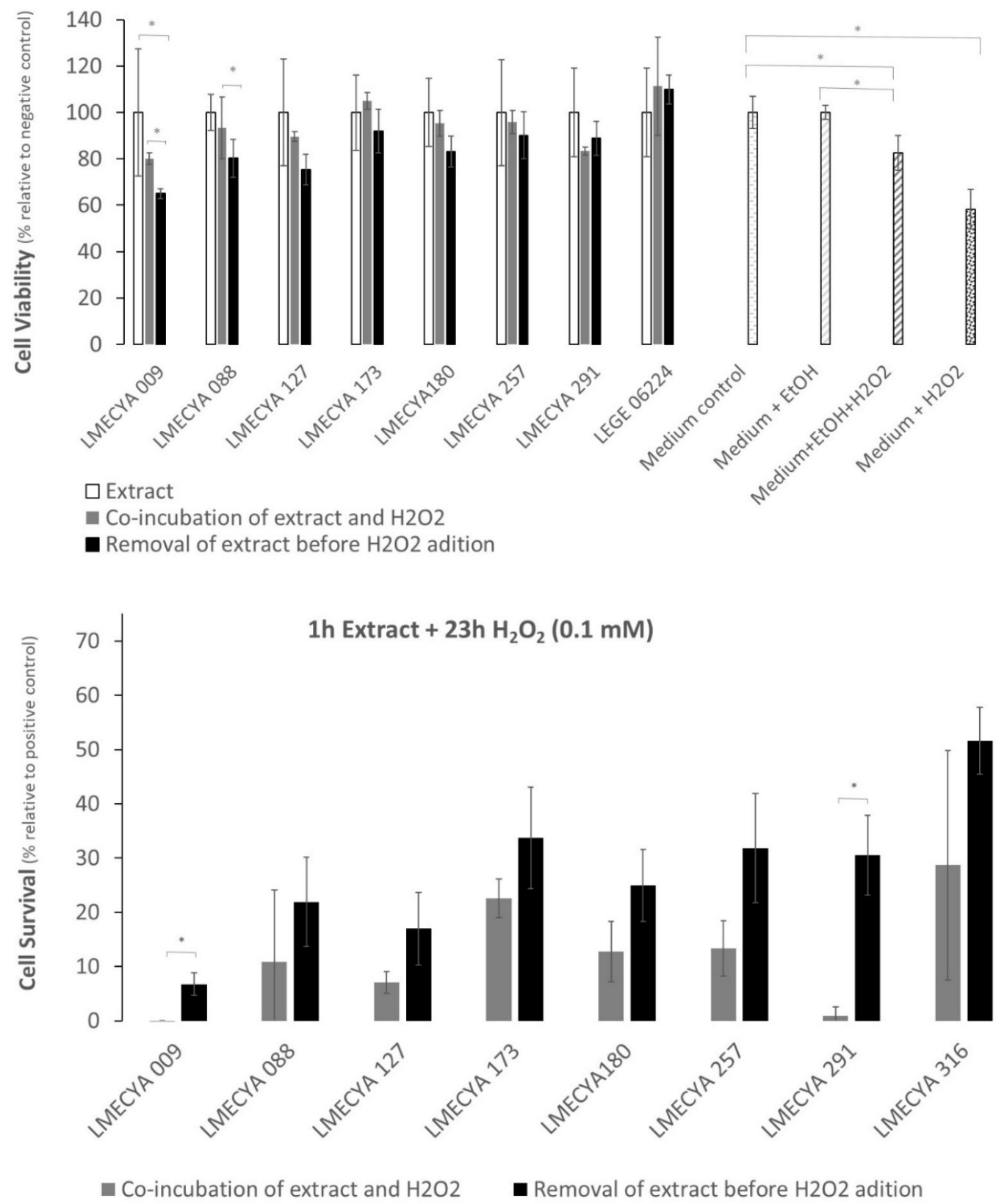

Figure 6. Viability and survival percentage of HEK293T cells exposed to $\mathrm{H}_{2} \mathrm{O}_{2}(0.1 \mathrm{mM})$ for a long period $(23 \mathrm{~h})$ and to cyanobacterial extracts for a short period $(1 \mathrm{~h})$. Grey bars refer to co-incubation of cells with $\mathrm{H}_{2} \mathrm{O}_{2}$ and cyanobacterial extracts. Black bars correspond to pre-incubation of cells with extracts before $\mathrm{H}_{2} \mathrm{O}_{2}$ exposure. White bars refer to cell exposure to cyanobacterial extracts only. White-dotted bars refer to the distinct controls. * represents a statistically significant difference $(p<0.05)$.

The results were somehow different when cells were exposed for a long period to cyanobacterial extracts $(23 \mathrm{H})$ and a short period $(3 \mathrm{~h})$ to a $10 \times$ higher $\mathrm{H}_{2} \mathrm{O}_{2}$ concentration $(1 \mathrm{mM})$. The viability of 
cells pre-treated with cyanobacterial extracts (with or without a wash step) decreased between $43 \%$ and $65 \%$ (Figure 7 , top) after $\mathrm{H}_{2} \mathrm{O}_{2}$ exposure when compared with cells exposed only to cyanobacterial extracts. In general, cell survival (Figure 7, bottom) varied between $5 \%$ and $30 \%$, and the inclusion of an extract-wash step before $\mathrm{H}_{2} \mathrm{O}_{2}$ exposure yielded the highest percentages.

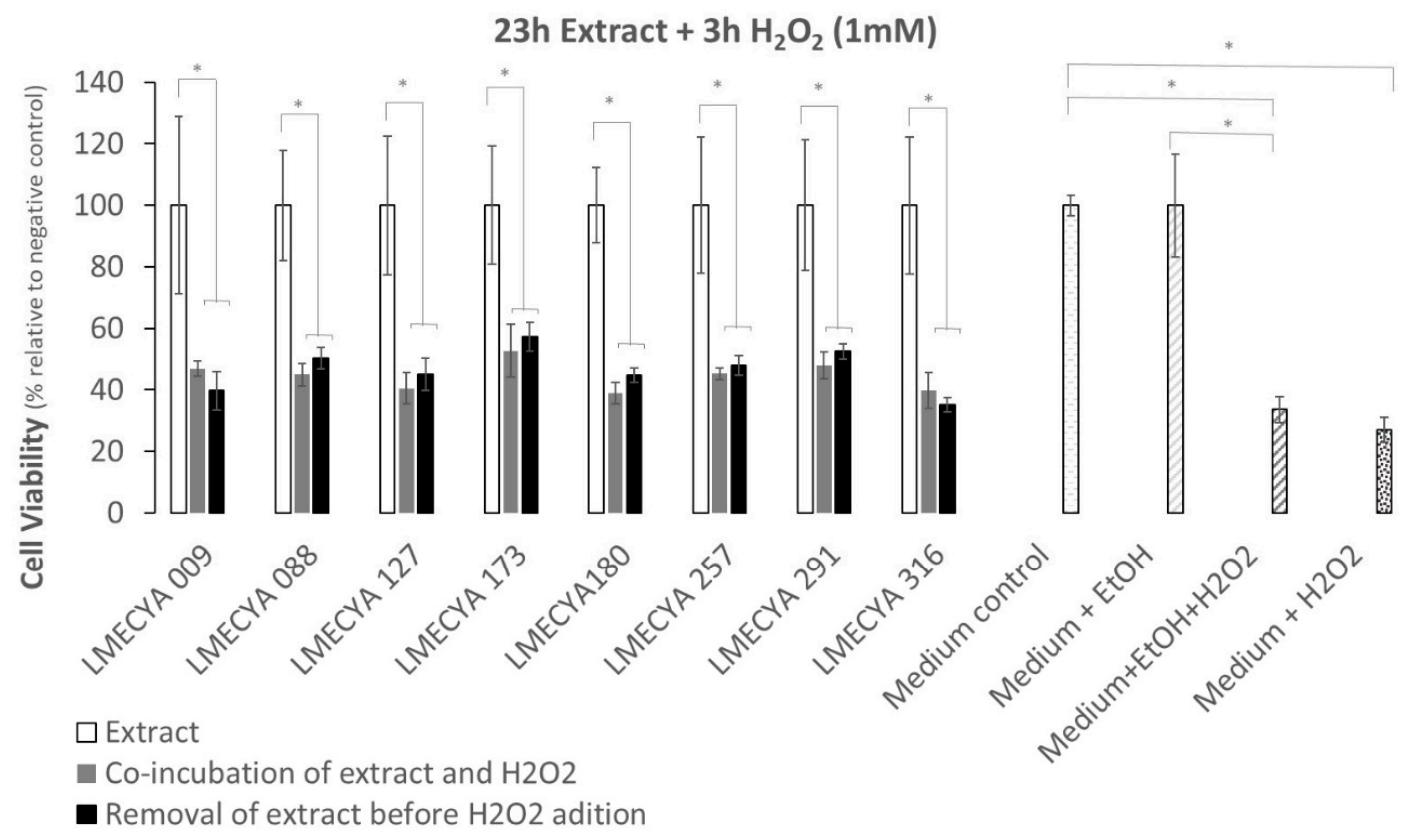

$23 \mathrm{~h}$ Extract $+3 \mathrm{~h} \mathrm{H}_{2} \mathrm{O}_{2}(1 \mathrm{mM})$

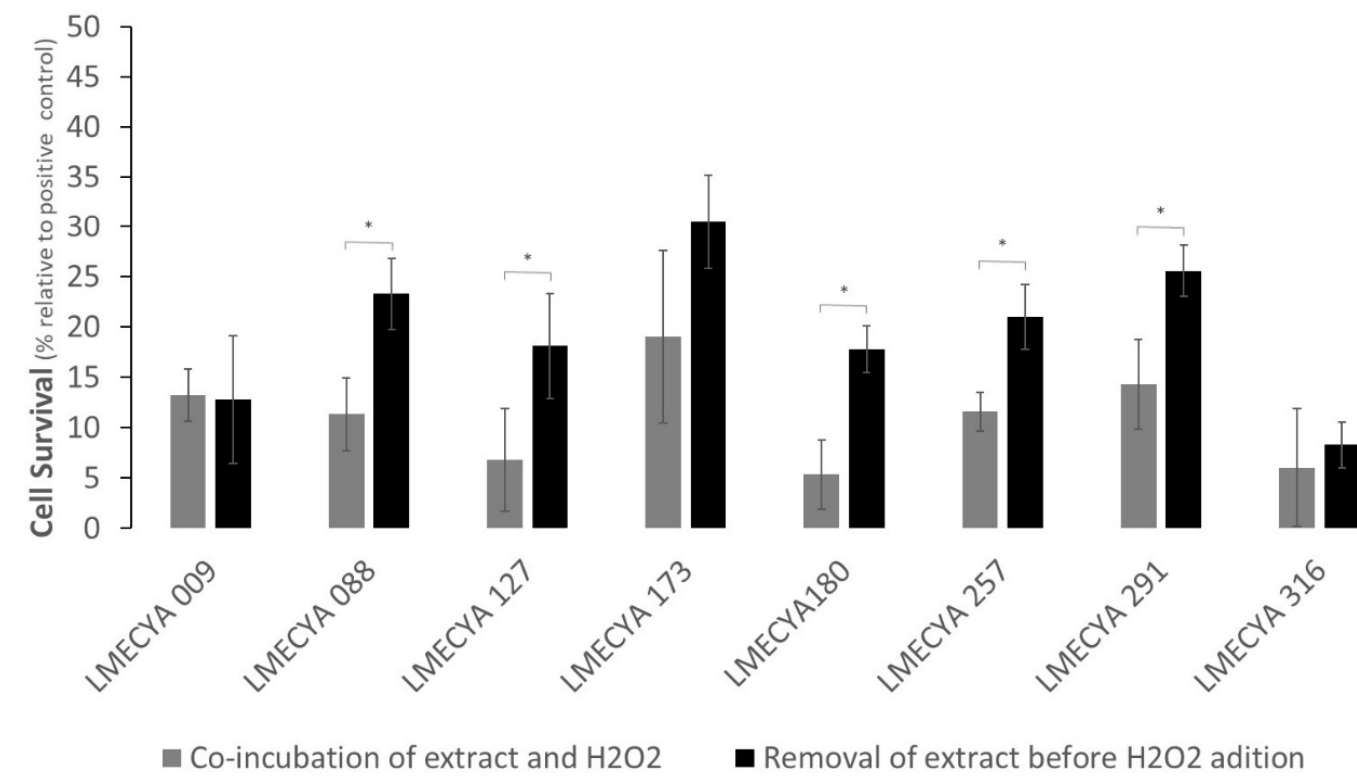

Figure 7. Viability and survival percentage of HEK293T cells exposed to $\mathrm{H}_{2} \mathrm{O}_{2}(1 \mathrm{mM})$ for a short period $(3 \mathrm{~h})$ and to cyanobacterial extracts for a long period $(23 \mathrm{~h})$. Grey bars refer to co-incubation of cells with $\mathrm{H}_{2} \mathrm{O}_{2}$ and cyanobacterial extracts. Black bars correspond to pre-incubation of cells with extracts before $\mathrm{H}_{2} \mathrm{O}_{2}$ exposure. White bars refer to cell exposure to cyanobacterial extracts only. White-dotted bars refer to the distinct controls. * represents a statistically significant difference $(p<0.05)$.

Interestingly, many extracts showed more than $25 \%$ of survival in the short extract/long $\mathrm{H}_{2} \mathrm{O}_{2}$ exposure. Extracts from strains LMECYA 173, LMECYA 257, LMECYA 291 and LEGE 06224 were the 
most effective. In the case of long extract/short $\mathrm{H}_{2} \mathrm{O}_{2}$ exposure, only extracts from strains LMECYA 173 and LMECYA 291 presented a survival rate above $25 \%$.

\section{Discussion}

This work aimed to evaluate the antioxidant profile of cyanobacterial strains of different species, isolated from freshwaters, wastewater and soil. Antioxidant profiles varied with strain and extraction solvent.

According to the DPPH inhibition assay, methanolic extracts of all strains presented higher antioxidant activity than the ethanolic extracts (except for LEGE 06224, which showed similar results with both extracts). It has been described that methanol is more effective than ethanol in extracting antioxidant compounds $[5,17,26]$, probably due to its high polarity [16]. However, ethanolic extracts presented higher yields for most of the strains by the $\beta$-carotene bleaching, total phenolic and total flavonoid assays. This is not surprising since the DPPH assay measures the overall antioxidant capacity of a mixture [26], whereas the other assays are more specific for certain compounds. Besides, the effectiveness of the extraction solvents depends on the nature of the compounds to be extracted. Nevertheless, we should bear in mind that methanol might not be a proper solvent for certain biotechnological applications of cyanobacterial antioxidants. For example, Food and Drug Administration excludes methanol, but not ethanol, from the GRAS (Generally Recognized as Safe) list for food/food packaging industry, due to its recognized toxicity to humans [27].

The extracts (methanolic) from M. aeruginosa (LMECYA 127), Leptolyngbya sp. (LMECYA 173), Dolichospermum flos-aquae (LMECYA 180), Planktothrix agardhii (LMECYA 257) and Planktothrix mougeotii (LEGE 06224) showed the higher yields of antioxidant activity by the DPPH assay with values ranging from $8.8 \% \mathrm{IP}(17.3 \mathrm{TE} \mu \mathrm{g} / \mathrm{mL})$ to $10.7 \% \mathrm{IP}(20.7 \mathrm{TE} \mu \mathrm{g} / \mathrm{mL})$. These values are similar to those obtained with methanolic extracts of Leptolyngbya protospira (7.65\%), Nodularia spumigena (13.02\%) e Phormidiochaete sp. (14.59\%) [5], Cylindrospermum sp. (7\%) [20], Plectonema boryanum (8.5\%) and Anabaena doliolum (11.3\%) [19]. However, higher values were reported in Nostoc sp., (28-100\%) [5,13,20], in Oscillatoria agardhii (51-92\%) and Anabaena sphaerica (39-62\%) [16] and in Phormidium fragile (25.5\%), Lyngbya limnetica (34.5\%), Scytonema bohnerii (30.8\%) and Calothrix fusca (21.3\%) [17].

Our results of DPPH inhibition assay are quite comparable with previous results obtained with methanolic extracts (1 mg DW/mL) of brown algae (Bifucaria bifurcata and Fucus spiralis) and green algae (Enteromorpha intestinalis and Ulva rigida), that varied between 10\% and 15\% [24]. On the other hand, Martins et al. [28] reported DPPH inhibition activity ranging from $11 \%$ and $80 \%$ in methanolic extracts $(1 \mathrm{mg} / \mathrm{mL})$ of 26 macroalgae species. As for macroalgae, results from DPPH assay in cyanobacteria seems to strongly depend on the species.

Indeed, species-specific results were also reported for other antioxidant endpoints, including pigments such as carotenes [29,30]. However, other authors highlighted that strains of the same genus may have a similar pattern of pigments [31]. In fact, in our study, the extracts (ethanolic) of Aphanizomenon gracile (LMECYA 009) and Aphanizomenon flos-aquae (LMECYA 088) showed significantly higher values in the $\beta$-carotene bleaching assay (690.47 and 828.94 AAC respectively) than the other tested strains. It is difficult to compare these results with others obtained with cyanobacteria because they are expressed in other units. However, our results are within the range [600-5000 AAC] of values reported for ethanolic extracts $(1 \mathrm{mg} / \mathrm{mL})$ of several eukaryotic microalgae (Porphyridium cruentum, Phaeodactylum tricornutum and Chlorella vulgaris) [32]. More concentrated extracts of those strains, particularly C. vulgaris, produce even higher values (up to 22,000 AAC) and the authors considered that those results were the highest activity ever registered with biological extracts by the $\beta$-carotene bleaching assay.

Some authors have studied the carotenoid profile of cyanobacteria and quantified the individual compounds. Lopes et al. [29], for example, investigated several species from different habitats and found that the terrestrial Nodosilinea (Leptolyngbya) antarctica (LEGE13457) and the freshwater Cyanobium gracile LEGE12431 presented the highest content in carotenoids, namely of $\beta$-carotene $(27.7 \mu \mathrm{g} / \mathrm{g}$ and 
$24.0 \mu \mathrm{g} / \mathrm{g}$, respectively). Another study with cyanobacteria from rice paddies, showed $\beta$-carotene levels ranging from $1221 \mu \mathrm{g} / \mathrm{g}$ (Nostoc calcicole; soil) to $8132 \mu \mathrm{g} / \mathrm{g}$ (Anabaena vaginicola; water) [21]. These studies demonstrate that both terrestrial and freshwater cyanobacteria might be important natural sources of carotenoids. Indeed, as noted by Hashtroudi et al. [21], carrot juice, pumpkin and cooked sweet potato are the three foods with the highest content of $\beta$-carotene, 93, 69 and $115 \mu \mathrm{g} / \mathrm{g}$, respectively, according to the U.S. Department of Agriculture (USDA-SR24). The same authors also highlight that the highest content of $\beta$-carotene has been reported for the commercialized microalgae, Dunaliella salina and Dunaliella bardawil (11,000-21,000 $\mu \mathrm{g} / \mathrm{g} \mathrm{dw})$ [21].

In our study, the ethanolic extracts also showed the highest values of phenolic compounds, which varied between 34.2 and $123 \mathrm{mg}$ EAG/g of DW. Aphanizomenon gracile (LMECYA 009) and Aphanizomenon flos-aquae (LMECYA 088) exhibited the highest values (102.32 and $123.16 \mathrm{mg}$ EAG/g DW, respectively). These results are similar and/or higher than those observed in other studies. Bavini [12] reported a total phenolic content of 5.4 to $28 \mathrm{mg} \mathrm{EAG} / \mathrm{mg}$ of extract $(10 \mathrm{mg} / \mathrm{mL}$, ethanolic extraction) in eight strains of marine and freshwater cyanobacteria. The higher content was observed in Synechocystis salina (marine) and Phormidium sp. (freshwater). Yasin et al. [11] described a range of total phenolic compounds from 15.1 to $96.7 \mathrm{mg}$ EAG/mg, depending on the solvent, in the freshwater Nostoc muscorum NCCU-442. In a study from Singh et al. [6] with twenty terrestrial cyanobacterial strains, total phenolic content (methanolic extracts) varied between $22 \mathrm{mg}$ EAG/g (Aulosira fertilissima) and $290 \mathrm{mg}$ EAG/g (Oscillatoria acuta). However, a direct comparison cannot be done because these authors extracted cyanobacteria biomass with methanol, and they did not specify the extract concentration. Also, Rajishamol et al. [15] evaluated the total phenolic content of methanolic extracts $(100 \mu \mathrm{g} / \mathrm{mL})$ of the freshwater Oscillatoria limosa (33.4 mg EAG/g), Synechococcus elongatus (21.33 mg EAG/g) and Synechocystis aquatilis (15.94 mg EAG/g). Aydaş et al. [33] reported a maximum of $78.1 \mu \mathrm{g}$ EAG/mg in Synechocystis sp. BASO673 (methanolic extract, $0.1 \mathrm{~g} / \mathrm{mL}$ ). El-Aty et al. [16] registered $14.8 \mathrm{mg}$ EAG/g and $20.9 \mathrm{mg}$ EAG/g in methanolic extracts of Anabaena sphaerica and Oscillatoria agardhii, respectively, but the authors did not indicate the extract concentration. The total phenolic content in strains of Dolichospermum flos aquae (4.38 mg EAG/g) and Nostoc ellipsosporum (39.9 mg EAG/g) were reported by Li et al. [18], but in this study other solvents (water, hexane, ethyl acetate) were used and the concentration of the extract was not mentioned in the paper. Hossain et al. [14] reported lower total phenolic content in aqueous extracts of Oscillatoria sp. (2.96 mg EAG/g), Lyngbya sp. (5.02 mg EAG/g), Microcystis sp. (2.65 mg EAG/g) and Spirulina sp. (1.78 EAG/g). When comparing these data with other natural sources of antioxidants, the potential of cyanobacteria becomes obvious. In brown algae (Bifucaria bifurcata and Fucus spiralis) for example, the total phenolic content varied between $1 \mathrm{mg}$ EAG/g and $29.8 \mathrm{mg} \mathrm{EAG} / \mathrm{g}$, depending on the extraction solvent [24]. It is also interesting to compare cyanobacterial results with green tea, which is considered a powerful natural antioxidant, due to its high content of gallic acid, among other compounds [25]. A study on the applicability of green tea in antioxidant-active food packaging showed a variation of total phenolic content between $272 \mathrm{mg} \mathrm{EAG/g}$ and $416 \mathrm{mg} \mathrm{EAG/g}$, in several green tea samples [25].

In the present study, ethanolic extracts of Aphanizomenon gracile (LMECYA 009) and Aphanizomenon flos-aquae (LMECYA 088) also showed significantly higher values of flavonoid content (605.58 and $900.60 \mathrm{mg}$ EQR/g DW, respectively). In the other tested strains, the highest values were observed in methanolic extracts and varied between 127.8 and $371.3 \mathrm{mg}$ EQR/g DW. These results are higher than those obtained in some previous studies with cyanobacteria. Singh et al. [6], for example, reported total flavonoid content 1000 times lower in methanolic extracts of 15 terrestrial cyanobacteria (53-634 $\mu \mathrm{g} \mathrm{EQR/g).} \mathrm{In} \mathrm{methanolic} \mathrm{extracts} \mathrm{of} \mathrm{freshwater} \mathrm{species,} \mathrm{El-Aty} \mathrm{et} \mathrm{al.} \mathrm{[16]} \mathrm{reported}$ values of $3.54 \mathrm{mg}$ EQR/g DW (Anabaena sphaerica) and $12.11 \mathrm{mg}$ EQR/g DW (Oscillatoria agardhii). Hossain et al. [14], on the other hand, described similar results in aqueous extracts of freshwater Oscillatoria sp. (552.59 mg EQR/g), Lyngbya sp. (664.07 mg EQR/g), Microcystis sp. (392.00 mg EQR/g) and Spirulina sp. (483.33 mg EQR/g). Lower total flavonoid content was also reported in macroalgae, such as the study of Osuna-Ruiz et al. [22] with methanolic extracts of Caulerpa sertularioides, Codium 
isabelae, Gracilaria vermiculophylla, Padina durvillaei, Rhizoclonium riparium, Spyridia filamentosa and Ulva expansa (10 to $14 \mathrm{mg}$ EQR/g dw). Raja et al. [23] described concentrations between 8 and $55 \mathrm{mg}$ EQR/g DW in methanolic extracts (2 mg/mL) of Codium fragile, Ulva lactuca and Eisenia arborea.

A comparison of the results among studies might be difficult given the differences in the endpoints and methods used to access antioxidant properties. Besides, differences among strains in the same study should also be considered. In our work, the tested strains have very distinct morphologies, colony structure and growth behaviour in vitro (distinct growth rates, cell agglomeration, adhesion to culture vessel walls, centrifugation behavior, etc.). All of these aspects are reflected in biomass productivity. Additionally, cell dimensions are also distinct and, as such, the cell density for the same dry weight varies between strains, but this is not considered when expressing the antioxidant yield by dry weight. To normalize these variations, we determined the antioxidant content per cell (or per cellular volume) for each strain. With this normalization, we found that Nostoc sp. (LMECYA 291) distinguished itself from all the other strains, with antioxidant levels per cell (or per cellular volume) one to three orders of magnitude higher.

Indeed, several studies have highlighted Nostoc spp. has a promising natural source of antioxidants, comparing with other cyanobacteria [11,21,34]. Nostoc commune, for example, is considered a UV-tolerant cyanobacterium [3], because this species produces significant amounts of mycosporine-like amino acids (MAAs), that function as a primary sunscreen [4]. It is known that environmental conditions may influence the variety and quantity of antioxidants in cyanobacteria and that these environmental variations may change daily or seasonally for cyanobacteria in their natural habitats [34]. Nostoc commume, as other Nostoc spp., is commonly found in terrestrial ecosystems where it is highly exposed to sunlight and subjected to dissection periods. For this reason, these species developed protection strategies such as the production of MAAs and gelatinous matrices formed by polysaccharides that surround Nostoc cells preventing dissection [35].

In the present work, we also investigated the biological activity of cyanobacterial extracts. For that purpose, we evaluated the protective effect of the ethanolic extracts of the eight cyanobacteria strains against $\mathrm{H}_{2} \mathrm{O}_{2}$-induced cytotoxicity in the HEK293T human cell line by the MTT assay. This human cell line is commonly used as a model for the investigation of $\mathrm{H}_{2} \mathrm{O}_{2}$-induced oxidative stress, being often used in studies of the antioxidant activity of natural compounds [36,37]. Pre-exposure of these cells to the majority of the cyanobacterial extracts protected them from the oxidative effect of $\mathrm{H}_{2} \mathrm{O}_{2}$. Survival was higher (between 7\% and 52\%) in cells pre-exposed to the extracts for $1 \mathrm{~h}$ and treated with $0.1 \mathrm{mM} \mathrm{H}_{2} \mathrm{O}_{2}$ for $23 \mathrm{~h}$ than in cells pre-exposed to the extracts for $23 \mathrm{~h}$ and treated with $1 \mathrm{mM} \mathrm{H}_{2} \mathrm{O}_{2}$ for $3 \mathrm{~h}$ (between $5 \%$ and $30 \%$ ). That is, the protective effect of the extracts against the oxidative effect of $\mathrm{H}_{2} \mathrm{O}_{2}$ depends on the time of exposure to the extracts and/or the concentration of the oxidizing agent.

To our knowledge, there are no reported data on the protective effect of cyanobacterial extracts against $\mathrm{H}_{2} \mathrm{O}_{2}$-induced oxidative stress in human cell lines, as has already been described for other natural compounds such as ferrulic acid, a natural phenolic present in plants and fruits [36] and Phyllanthus phillyreifolius, an endogenous pant used in traditional medicine in Réunion island [37]. However, a study by Badr et al. [38] revealed a decrease in oxidative stress markers and an increase in endogenous antioxidant defenses in rats under $\mathrm{H}_{2} \mathrm{O}_{2}$-induced oxidative stress, when orally consuming an extract of the cyanobacterial strain Sphaerospermopsis aphanizomenoides. In the present study, the extracts of Nostoc sp. (LMECYA 291), Planktothrix mougeotii (LEGE06224), Planktothrix agardhii (LMECYA 257) and Leptolyngbya sp. (LMECYA 173) conferred higher protection. These extracts have not exhibited the highest phenolic and flavonoid content. This suggests that other type of compounds present in this extract may be involved in the observed protective activity in HEK293T cells.

\section{Conclusions}

In this work, we demonstrate the antioxidant potential of several cyanobacterial strains from distinct habitats. Overall, freshwater Aphanizomenon gracile (LMECYA 009), Aphanizomenon flos-aquae (LMECYA 088), terrestrial Nostoc sp. (LMECYA 291) and wastewater Planktothrix mougeotii (LEGE 06224) 
seem promising for future studies on biotechnological applications in the field of antioxidants, namely in food, cosmetic and pharmaceutical areas. Further studies would be important to identify the mechanisms underlying the antioxidant activity of these strains and to characterize chemically their antioxidant compounds.

\section{Materials and Methods}

\subsection{Chemicals and Reagents}

Absolute ethanol, methanol and chloroform (analytical grade), Folin \& Ciocalteu's phenol reagent, sodium carbonate anhydrous, aluminum chloride, sodium hydroxide and Foetal Bovine Serum (FBS) were purchased from Merck (Darmstadt, Germany). 2,2-diphenyl-1-picrylhydrazyl (DPPH), 6-hydroxy-2,5,7,8-tetramethylchroman-2-carboxylic acid (Trolox) (purity 97\%), $\beta$-carotene (purity 97.0\%), linoleic acid (purity 97.0\%), Tween ${ }^{\circledR} 40$, (-)-epigallocatechin gallate (purity $\geq 95 \%$ ), sodium nitrite, quercetin (purity $\geq 95 \%$ ), Dulbecco's Modified Eagle's Medium (DMEM) and 3-(4,5-Dimethyl-2-thizaolyl)-2,5-diphenyl-2H-tetrazolium bromide (MTT) assay were purchased from Sigma-Aldrich (Madrid, Spain). Glucose, Glutamax ${ }^{\mathrm{TM}}$ and Trypsin were purchased from Gibco-ThermoFisher Scientific (Dublin, Ireland). Plasmocin ${ }^{\mathrm{TM}}$ was purchased InvivoGen (Toulouse, France).

\subsection{Cyanobacterial Strains Maintenance and Biomass Production}

In this work, six strains isolated from Portuguese surface freshwater reservoirs, one strain isolated from a soil sample and one strain from a wastewater treatment plant (WWTP) were studied.

The freshwater/soil strains belong to the "Estela Sousa e Silva Algae Culture Collection" (ESSACC) and the WWTP strain belongs to the "Blue Biotechnology and Ecotoxicology Culture Collection" (LEGE), as shown in Table 1. These strains were maintained in a culture chamber at $20^{\circ} \mathrm{C}$, with light intensity of $16 \pm 4 \mu \mathrm{Em}^{-2} \mathrm{~s}^{-1}$ and under a $14 / 10 \mathrm{~h}$ light/dark cycle in Z8 medium [39]. Large-scale cultures $(5 \mathrm{~L})$ of each strain were prepared in the same conditions and with air-bubbling to ensure nutrients and air mixing and avoid cell deposition. After reaching the exponential growth phase, cyanobacteria biomass was collected by decantation and centrifugation $\left(9600 \times g, 5 \mathrm{~min} ., 4^{\circ} \mathrm{C}\right.$; Beckman J2-14 M/E, Newton, CT, USA). The resulting cellular pellets were freeze-dried (Thermo Scientific Savant Speedvac AES 1000, Waltham, MA, USA) before the extraction of cyanobacterial compounds. Before decantation, a sample of $10 \mathrm{~mL}$ was taken for cell counting using Sedgwick-Rafter chambers under an inverted microscope [40]. This sample was also used for measurement of cell dimensions under an optical microscope BX60 coupled with a CCD camera DP11 (Olympus, Tokyo, Japan).

Table 1. Cyanobacterial strains, species and origins.

\begin{tabular}{ccc}
\hline Cyanobacterial Species & Strain Code & Strain Origin \\
\hline & Freshwater strains (ESSACC collection) & \\
\hline Dolichospermum flos-aquae & LMECYA 180 & Guadiana River/1999 \\
Aphanizomenon flos-aquae & LMECYA 088 & Montargil Reservoir/1999 \\
Aphanizomenon gracile & LMECYA 009 & Peneireiro Reservoir1996 \\
Leptolyngbya sp. & LMECYA 173 & Hydrothermal fountain /2003 \\
Microcystis aeruginosa & LMECYA 127 & Montargil reservoir/2000 \\
Nostoc sp. & LMECYA 291 & Garden soil /2013 \\
Planktothrix agardhii & LMECYA 257 & São Domingos Reservoir /2009 \\
\hline Planktothrix mougeotii & WWTP strain (LEGE collection) & \\
\hline
\end{tabular}




\subsection{Preparation of Cyanobacterial Extracts}

Cyanobacterial biomass was submitted to a solid-liquid extraction in two distinct solvents: absolute ethanol and methanol. Briefly, three sub-samples of lyophilized biomass ( $0.5 \mathrm{~g})$ from each cyanobacteria strain were mixed with $10 \mathrm{~mL}$ of each of the solvents and stirred at $350 \mathrm{rpm}$ for $30 \mathrm{~min}$. at room temperature, in a horizontal compact stirrer (Edmund Bühler GmbH_KS-15, Hechingen, Germany). The suspensions were centrifuged for $10 \mathrm{~min}$ at $5160 \times g$ in a Thermo Scientific centrifuge (Heraeus Multifuge X3, Altrincham, England). The supernatant was transferred to a pyriform flask and the solvent was totally evaporated in a rotary evaporator (Büchi_R-210, Labortechnik, Switzerland) at $35{ }^{\circ} \mathrm{C}$. The resulting dry residue was weighted, diluted with the corresponding solvent to a final concentration of $1 \mathrm{mg}$ extract $\mathrm{DW} / \mathrm{mL}$ and stored at $-80{ }^{\circ} \mathrm{C}$.

\subsection{Evaluation of Antioxidant Potential of Cyanobacterial Extract by Chemical Methods}

The antioxidant activity of methanolic and ethanolic cyanobacterial extracts was evaluated by the DPPH radical scavenging method and by the $\beta$-carotene bleaching assay. The total phenolic compounds and flavonoid were also determined in those extracts. All procedures were performed in triplicate.

\subsubsection{DPPH Scavenging Method}

The reduction of DPPH radical by cyanobacterial extracts was evaluated according to the method described in Andrade et al. [41]. Briefly, $50 \mu \mathrm{L}$ of each cyanobacterial extract was added to a $2 \mathrm{~mL}$ methanolic solution of DPPH at $14.6 \mu \mathrm{g} / \mathrm{mL}$. The blank assay consisted of $50 \mu \mathrm{L}$ of the corresponding solvent extract. Three replicates of each sample extract and blank were prepared. The samples were incubated for $30 \mathrm{~min}$ in the dark at room temperature. The absorbance was measured at $515 \mathrm{~nm}$ in a spectrophotometer X1_Evolution_300 (Thermo Scientific, Altrincham, England). Radical scavenging capacity was expressed as an inhibition percentage (\% IP) of DPPH and calculated using the Equation (1):

$$
(\%) \mathrm{IP}=[(\mathrm{Ac}-\mathrm{As} 30) / \mathrm{Ac}] \times 100
$$

where: (\%) IP-Inhibition percentage of DPPH radical; Ac-Absorbance of the blank; As30-Absorbance of the sample after $30 \mathrm{~min}$. of reaction.

The antioxidant capacity was expressed in $\mu \mathrm{g}$ Trolox equivalents per $\mathrm{mL}$ of extract $(\mu \mathrm{g} \mathrm{TE} / \mathrm{mL})[41,42]$. For this purpose, a calibration curve of Trolox was prepared $(\mathrm{y}=0.5439 \mathrm{x}-$ $\left.0.5861 ; r^{2}=0.9999\right)$, using standard methanolic solution of Trolox, ranging from 10 to $175 \mu \mathrm{g} / \mathrm{mL}$.

\subsection{2. $\beta$-carotene Bleaching Assay}

This assay was performed according to Andrade et al. [41]. The method is based on the ability of the different extracts to decrease oxidative losses of $\beta$-carotene in a $\beta$-carotene/linoleic acid emulsion. A solution of $\beta$-carotene at a concentration of $0.2 \mathrm{mg} / \mathrm{mL}$ was prepared by dissolving $2 \mathrm{mg}$ of $\beta$-carotene in $10 \mathrm{~mL}$ of chloroform. In a pear-shaped flask, $200 \mathrm{mg}$ of Tween ${ }^{\circledR} 40,20 \mathrm{mg}$ of linoleic acid and $1 \mathrm{~mL}$ of the $\beta$-carotene solution were added. Chloroform was evaporated at $40{ }^{\circ} \mathrm{C}$ in a rotary evaporator RE-111 with a vacuum pump V-700 from BÜCHI (Flawil, Switzerland). Then, $50 \mathrm{~mL}$ of Milli-Q ${ }^{\mathrm{TM}}$ distilled water were added and the mixture was vigorously shaken to form an emulsion. Then, $0.2 \mathrm{~mL}$ of cyanobacterial extracts were added to $5 \mathrm{~mL}$ of the $\beta$-carotene emulsion. The samples were submitted to $50{ }^{\circ} \mathrm{C}$ for $2 \mathrm{~h}$, in a heating block QBD2 of Grant Instruments (Cambridge, England). For the blank assays, $0.2 \mathrm{~mL}$ of the corresponding extract solvent was used. The absorbance of the blank assays was measured at $470 \mathrm{~nm}$ before and after $2 \mathrm{~h}$ of reaction $\left(\right.$ at $50^{\circ} \mathrm{C}$ ) and the absorbance of the samples was measured only after $2 \mathrm{~h}$ at the same wavelength. The Antioxidant Activity Coefficient (AAC) was calculated by the Equation (2):

$$
\mathrm{AAC}=(\mathrm{AS} 120-\mathrm{AC} 120) /(\mathrm{AC} 0-\mathrm{AC} 120) \times 1000
$$


where: AAC_Antioxidant Activity Coefficient; AAS120_Absorbance of the sample after 120 min. of reaction; AC120-Absorbance of the blank after 120 min. of reaction; ACO_Absorbance of the blank at the initial time.

\subsubsection{Determination of Total Phenolic Compounds}

The method was adapted from Erkan et al. [43]. The assay is based on the reduction of the Folin-Cioucalteau reagent by the putative antioxidant compounds of the samples. Briefly, $1 \mathrm{~mL}$ of cyanobacterial extracts was added to $7.5 \mathrm{~mL}$ of Folin-Cioucalteau reagent $(1: 10, v / v)$ and maintained at room temperature. After $5 \mathrm{~min}, 7.5 \mathrm{~mL}$ of an aqueous sodium carbonate solution $(6 \mathrm{mg} / \mathrm{mL})$ was added and the solution was kept in the dark, at room temperature for $2 \mathrm{~h}$. The absorbance was measured at $725 \mathrm{~nm}$. The total content in phenolic compounds were calculated based on the calibration curve of Gallic acid (range: 0.025 to $0.2 \mathrm{mg} / \mathrm{mL} ; \mathrm{y}=6.3518 \mathrm{x}+0.112, r^{2}=0.9992$ ) and expressed as Gallic acid equivalents (GAE), in milligrams per gram of the extract (mg GAE/g DW).

\subsubsection{Determination of Total Flavonoid Compounds}

The total flavonoid content of the extracts was determined according to the method described by Yoo et al. [44]. One $\mathrm{mL}$ of the extract was mixed with $4 \mathrm{~mL}$ of distilled water and $0.3 \mathrm{~mL}$ of a $5 \%$ sodium nitrite solution. After $5 \mathrm{~min}, 0.6 \mathrm{~mL}$ of $10 \%$ aluminum chloride solution was added. Reaction proceeded for $6 \mathrm{~min}$ and, $0.2 \mathrm{~mL}$ of $1 \mathrm{M}$ sodium hydroxide and $2.3 \mathrm{~mL}$ of distilled water was added. The absorbance of the mixture was recorded at $510 \mathrm{~nm}$. The total flavonoid contents were calculated based on the calibration curve of quercetin (range: 0.1 to $0.7 \mathrm{mg} / \mathrm{mL} ; \mathrm{y}=0.8561 \mathrm{x}+0.0304, r^{2}=0.9971$ ) and expressed as quercetin equivalents (QE), in milligrams per gram of the extract (mg QE/g DW).

The results expressed in $\mu \mathrm{g}$ TE/mL (item 5.4.1), mg GAE/g DW (item 5.4.3) and $\mathrm{mg}$ QE/g DW (item 5.4.4) were subsequently converted to a "per cell" and to a "per cell volume $\left(\mu \mathrm{m}^{3}\right)$ " basis by dividing the values of each parameter by the corresponding cell density or cell volume, determined at the time of culture sampling, respectively.

5.5. Evaluation of the Protective Effect of Cyanobacterial Extracts against Hydrogen Peroxide Cytotoxicity in HEK293T Cell Line

\subsubsection{HEK293T Cell Line Maintenance and Exposure to Cyanobacteria Extracts and Hydrogen} Peroxide

The human embryonic kidney HEK293T cell line was used to test the protective effect of cyanobacterial ethanolic extracts against the $\mathrm{H}_{2} \mathrm{O}_{2}$-induced cytotoxicity. Cells were grown in Dulbecco's Modified Eagle's Medium (DMEM) supplemented with Foetal Bovine Serum (FBS, 10\%), glucose $(4.5 \mathrm{~g} / \mathrm{L})$, Glutamax ${ }^{\mathrm{TM}}$ and Plasmocin ${ }^{\mathrm{TM}}$ in a $5 \% \mathrm{CO}_{2}$ humidified incubator at $37^{\circ} \mathrm{C}$. Adherent cells in exponential growth phase were trypsinized (trypsin, $0.5 \%$ ), resuspended in culture medium and the cell density and viability were determined by the trypan blue dye exclusion method [45]. Six thousand viable cells were seeded per individual 96-microplate wells and maintained for $24 \mathrm{~h}$ for cell adherence and growth, prior to extract exposure. After the $24 \mathrm{~h}$ incubation period, the growth medium was removed and cells were exposed to cyanobacterial extracts for a short $(1 \mathrm{~h})$ and a long $(23 \mathrm{~h})$ period, prior to $\mathrm{H}_{2} \mathrm{O}_{2}$ addition (Figure 8). The extracts were diluted in culture medium at $10 \mu \mathrm{g}$ biomass $/ \mathrm{mL}$ and the corresponding ethanol (absolute, anhydrous) concentration was 1\%. After the short exposure to the extracts, $\mathrm{H}_{2} \mathrm{O}_{2}(0.1 \mathrm{mM}$ final concentration) was added to microplate wells and cells were incubated for additional $23 \mathrm{~h}$. After the long exposure to cyanobacterial extracts, cells were exposed to $\mathrm{H}_{2} \mathrm{O}_{2}$ (1 mM, final concentration) for $3 \mathrm{~h}$. In both conditions, the extracts were co-incubated with $\mathrm{H}_{2} \mathrm{O}_{2}$ (Figure 8). In parallel, cells were exposed to $\mathrm{H}_{2} \mathrm{O}_{2}(0.1 \mathrm{mM} / 23 \mathrm{~h}$ or $1 \mathrm{mM} / 3 \mathrm{~h})$ prepared in fresh DMEM medium but after removing the previous extract-containing medium (Figure 8). Cell exposed only to cyanobacterial extracts (microplate wells 1-3) represents the negative control of cells exposed to cyanobacterial extracts with $\mathrm{H}_{2} \mathrm{O}_{2}$ (microplate wells 4-9). Several additional controls were included 
in the assay: (a) negative control = culture medium (to confirm the basal cell growth); (b) solvent control = culture medium + ethanol absolute anhydrous at 1\% (to ensure that EtOH did not affect cell viability); (c) positive control $1=\mathrm{H}_{2} \mathrm{O}_{2}(0.1 \mathrm{mM}$ or $1 \mathrm{mM})$ in culture medium (to ensure $\mathrm{H}_{2} \mathrm{O}_{2}$ impaired cell viability); (d) positive control $2=\mathrm{H}_{2} \mathrm{O}_{2}(0.1 \mathrm{mM}$ or $1 \mathrm{mM})$ in culture medium $+\mathrm{EtOH}$ (to demonstrate that EtOH did not affect $\mathrm{H}_{2} \mathrm{O}_{2}$ effect). All the exposure conditions were tested in triplicate. Exposure conditions are outlined in Figure 8.

A
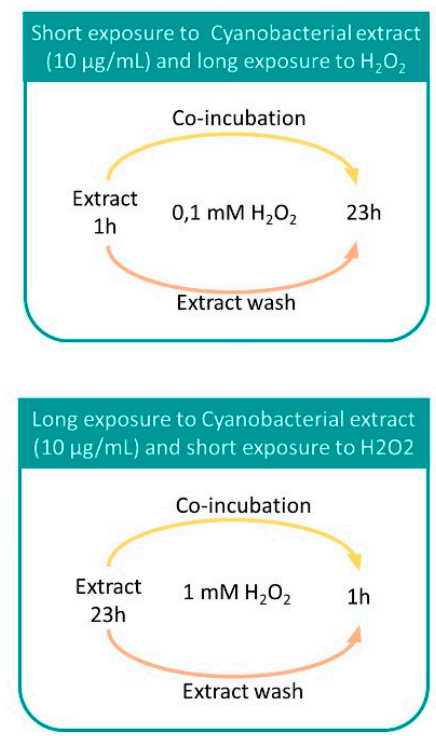

B

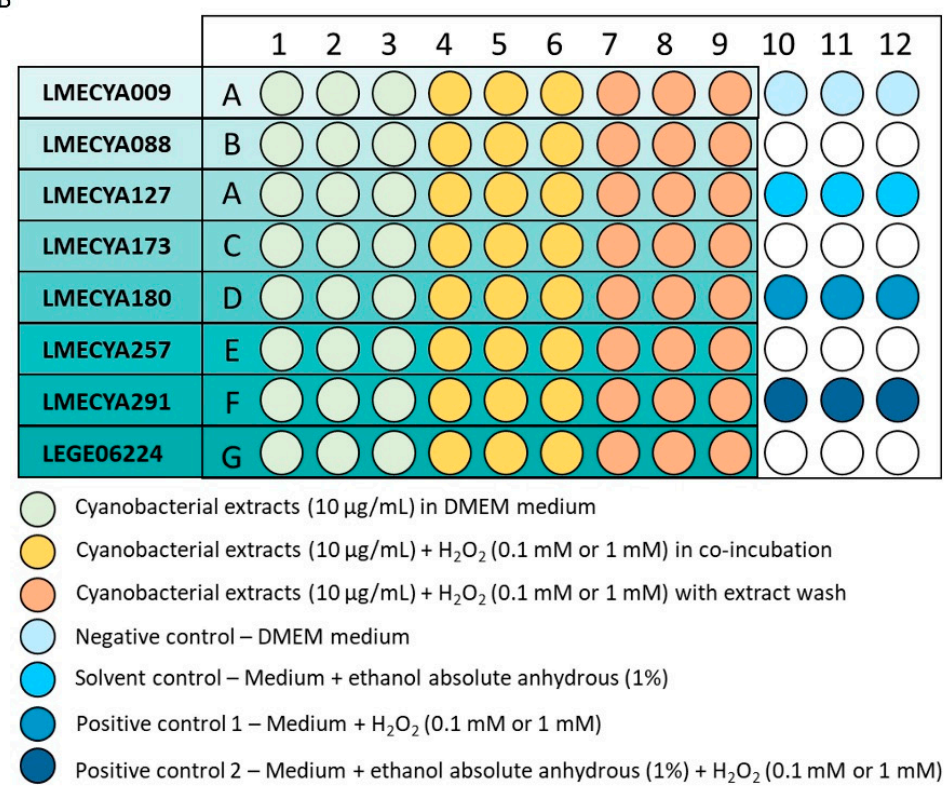

Figure 8. Exposure conditions of HEK293T cells to cyanobacterial extracts (LMECYA and LEGE strains), $\mathrm{H}_{2} \mathrm{O}_{2}$ and respective controls. (A) Types of exposure; (B) Schematic representation of the 96-microwell plate.

\subsubsection{MTT Assay}

The cell viability was evaluated by the 3-(4,5-Dimethyl-2-thizaolyl)-2,5-diphenyl-2H-tetrazolium bromide (MTT) assay [46]. Briefly, after the exposure period to cyanobacterial extracts and $\mathrm{H}_{2} \mathrm{O}_{2}$, the culture medium was removed from microplates and the cells were incubated for $3 \mathrm{~h}$ at $37^{\circ} \mathrm{C}$ with fresh culture medium containing $10 \%$ of MTT solution $(5 \mathrm{mg} / \mathrm{mL}$, in PBS). To dissolve the MTT-formazan crystals formed by healthy cells, the MTT containing medium was discharged and a solution of acidified propan-2-ol solution $(0.04 \mathrm{M} \mathrm{HCl})$ was added for 15 min under shaking. The absorbance was recorded at $570 \mathrm{~nm}$ using a Multiscan Ascent spectrophotometer (Labsystems, Helsinki, Finland).

Cell viability (\%) was determined by dividing the mean value of absorbance of each treatment by the mean value of the corresponding control $(\times 100)$. The viability results of cells exposed to cyanobacterial extracts $+\mathrm{H}_{2} \mathrm{O}_{2}$, with or without a wash step (Figures 6 and 7) were compared with the viability of cells exposed only to cyanobacterial extracts (Figures 6 and 7). In parallel, the additional 4 controls were compared with each other, as represented by the asterisks in Figures 6 and 7 .

Cell survival was calculated by subtracting the viability of positive control 1 (culture medium $+\mathrm{H}_{2} \mathrm{O}_{2}$ ) or positive control 2 (culture medium $+\mathrm{EtOH}+\mathrm{H}_{2} \mathrm{O}_{2}$ ) to the viability of cells exposed to cyanobacterial extract $+\mathrm{H}_{2} \mathrm{O}_{2}$, with or without a previous extract-wash step, respectively.

\subsection{Statistical Analysis}

The statistical analysis of data was done using the IBM SPSS statistics 25 software. The data comply with the normality. Data from the DPPH inhibition assay, $\beta$-carotene bleaching test, total phenolic and 
total flavonoid compounds was examined by One Way ANOVA using Tukey's (HSD) as post-hoc test. The analysis of the data obtained with MTT assay, to evaluate the protective effect of cyanobacterial extracts against $\mathrm{H}_{2} \mathrm{O}_{2}$ cytotoxicity in HEK293T cell line, was performed by Student's $t$-test. Differences were considered significant when $p<0.05$.

Supplementary Materials: The following are available online at http://www.mdpi.com/2072-6651/12/9/548/s1, Table S1: Cell volume and antioxidant content expressed "per cell" and "per cell volume" of cyanobacterial strains.

Author Contributions: Conceptualization, C.M., F.V. and E.D.; methodology, A.G., M.A.A., C.M., F.V. and E.D.; validation, A.G., M.A.A., C.M., F.V. and E.D.; formal analysis, A.G., M.A.A., C.M., F.V. and E.D.; investigation, A.G., M.A.A., C.M., F.V. and E.D.; writing-original draft preparation, E.D.; writing-review and editing, A.G., M.A., C.M., F.V. and E.D.; visualization, A.G., C.M. and E.D.; supervision, E.D.; project administration, C.M., F.V. and E.D. All authors have read and agreed to the published version of the manuscript.

Funding: This research received no external funding.

Acknowledgments: The HEK293T cell line and reagents for cell culture were kindly offered by Rafaela Lacerda, Department of Human Genetics, National Health Institute, Lisbon, Portugal.

Conflicts of Interest: The authors declare no conflict of interest.

\section{References}

1. Dvořák, P.; Casamatta, D.A.; Hašler, P.; Jahodářová, E.; Norwich, A.R.; Poulíčková, A. Diversity of the Cyanobacteria. In Modern Topics in the Phototrophic Prokaryotes; Hallenbeck, P., Ed.; Springer International Publishing: Cham, Switzerland, 2017; pp. 3-46. [CrossRef]

2. Dvořák, P.; Poulíčková, A.; Hašler, P.; Belli, M.; Casamatta, D.A.; Papini, A. Species concepts and speciation factors in cyanobacteria, with connection to the problems of diversity and classification. Biodivers. Conserv. 2015, 24, 739-757. [CrossRef]

3. Ehling-Schulz, M.; Scherer, S. UV protection in cyanobacteria. Eur. J. Phycol. 1999, 34, 329-338. [CrossRef]

4. Wada, N.; Sakamoto, T.; Matsugo, S. Mycosporine-Like Amino Acids and Their Derivatives as Natural Antioxidants. Antioxidants 2015, 4, 603-646. [CrossRef]

5. Martel, I.J.; Poza, S.G.; Martel, G.R.; Rico, M.; Olivares, C.A.; Pinchetti, J.L.G. Phenolic Profile and Antioxidant Activity of Crude Extracts from Microalgae and Cyanobacteria Strains. J. Food Qual. 2017, 2017, 2924508. [CrossRef]

6. Singh, D.P.; Prabha, R.; Verma, S.; Meena, K.K.; Yandigeri, M. Antioxidant properties and polyphenolic content in terrestrial cyanobacteria. 3 Biotech 2017, 7, 134. [CrossRef]

7. Babić, O.; Kovač, D.; Rašeta, M.; Šibul, F.; Svirčev, Z.; Simeunović, J. Evaluation of antioxidant activity and phenolic profile of filamentous terrestrial cyanobacterial strains isolated from forest ecosystem. J. Appl. Phycol. 2016, 28, 2333-2342. [CrossRef]

8. Morone, J.; Alfeus, A.; Vasconcelos, V.; Martins, R. Revealing the potential of cyanobacteria in cosmetics and cosmeceuticals-A new bioactive approach. Algal Res. 2019, 41, 101541. [CrossRef]

9. Singh, R.; Parihar, P.; Singh, M.; Bajguz, A.; Kumar, J.; Singh, S.; Singh, V.P.; Prasad, S.M. Uncovering Potential Applications of Cyanobacteria and Algal Metabolites in Biology, Agriculture and Medicine: Current Status and Future Prospects. Front. Microbiol. 2017, 8, 515. [CrossRef]

10. Andrade, M.A.; Lima, V.; Sanches-Silva, A.; Vilarinho, F.; Castilho, M.C.; Khwaldia, K.; Ramos, F. Pomegranate and grape by-products and their active compounds: Are they a valuable source for food applications? Trends Food Sci. Technol. 2019, 86, 68-84. [CrossRef]

11. Yasin, D.; Zafaryab, M.; Ansari, S.; Ahmad, N.; Khan, N.F.; Zaki, A.; Rizvi, M.M.A.; Fatma, T. Evaluation of antioxidant and anti-proliferative efficacy of Nostoc muscorum NCCU-442. Biocatal. Agric. Biotechnol. 2019, 17, 284-293. [CrossRef]

12. Bavini, J.M. Cyanobacteria in Skin Protection. Master's Thesis, Faculdade de Ciências Universidade do Porto, Porto, Portugal, 2018. Available online: https://repositorio-aberto.up.pt/bitstream/10216/118610/2/311491.pdf (accessed on 30 April 2020).

13. Geethu, V.; Shamina, M. Antioxidant activity of cyanobacterium Nostoc spongiaeforme C. Agardh ex Born. \& Flah. J. Algal Biomass Util. 2018, 9, 26-30. 
14. Hossain, M.F.; Ratnayake, R.R.; Meerajini, K.; Kumara, K.L.W. Antioxidant properties in some selected cyanobacteria isolated from freshwater bodies of Sri Lanka. Food Sci. Nutr. 2016, 4, 753-758. [CrossRef] [PubMed]

15. Rajishamol, M.P.; Lekshmi, S.; Vijayalakshmy, K.C.; Saramma, A.V. Antioxidant activity of Cyanobacteria isolated from Cochin estuary. Indian J. Geo Mar. Sci. 2016, 45, 974-977.

16. El-Aty, A.M.A.; Mohame, A.A.; Samhan, F.A. In vitro antioxidant and antibacterial activities of two fresh water Cyanobacterial species, Oscillatoria agardhii and Anabaena sphaerica. J. Appl. Pharm. Sci. 2014, 4, 69-75. [CrossRef]

17. Sharathchandra, K.; Rajashekhar, M. Antioxidant activity in the four species of cyanobacteria isolated from a sulfur spring in the western ghats of karnataka. Int. J. Pharma Bio Sci. 2013, 4, 275-285.

18. Li, H.B.; Cheng, K.W.; Wong, C.C.; Fan, K.W.; Chen, F.; Jiang, Y. Evaluation of antioxidant capacity and total phenolic content of different fractions of selected microalgae. Food Chem. 2007, 102, 771-776. [CrossRef]

19. Singh, D.P.; Prabha, R.; Meena, K.K.; Sharma, L.S.; Sharma, A.K. Induced Accumulation of Polyphenolics and Flavonoids in Cyanobacteria under Salt Stress Protects Organisms through Enhanced Antioxidant Activity. Am. J. Plant Sci. 2014, 5, 726-735. [CrossRef]

20. Zeeshan, M.; Suhail, S.; Biswas, D.; Farooqui, A.; Arif, J.M. Screening of Selected Cyanobacterial Strains for Phycochemical Compounds and Biological Activities in Vitro. Biochem. Cell. Arch. 2010, 10, 163-168.

21. Hashtroudi, M.S.; Shariatmadari, Z.; Riahi, H.; Ghassempour, A. Analysis of Anabaena vaginicola and Nostoc calcicola from Northern Iran, as rich sources of major carotenoids. Food Chem. 2013, 136, 1148-1153. [CrossRef]

22. Osuna-Ruiz, I.; López-Saiz, C.M.; Burgos-Hernández, A.; Velázquez, C.; Nieves-Soto, M.; Hurtado-Oliva, M.A. Antioxidant, antimutagenic and antiproliferative activities in selected seaweed species from Sinaloa, Mexico. Pharm. Biol. 2016, 54, 2196-2210. [CrossRef]

23. Raja, R.; Hemaiswarya, S.; Arunkumar, K.; Carvalho, I.S. Antioxidant activity and lipid profile of three seaweeds of Faro, Portugal. Rev. Bras. Bot. 2016, 39, 9-17. [CrossRef]

24. Chernane, H.; Mansori, M.; Latique, S.; El Kaoua, M. Evaluation of Antioxidant Capacity of Methanol Extract and Its Solvent Fractions Obtained From Four Moroccan Macro Algae Species. Eur. Sci. J. 2014, 10, 35-48. [CrossRef]

25. Martins, C.; Vilarinho, F.; Sanches Silva, A.; Andrade, M.; Machado, A.V.; Castilho, M.C.; Sá, A.; Cunha, A.; Vaz, M.F.; Ramos, F. Active polylactic acid film incorporated with green tea extract: Development, characterization and effectiveness. Ind. Crops Prod. 2018, 123, 100-110. [CrossRef]

26. Kedare, S.B.; Singh, R.P. Genesis and development of DPPH method of antioxidant assay. J. Food Sci. Technol. 2011, 48, 412-422. [CrossRef] [PubMed]

27. Food and Drug Administration (FDA). Substances GRAS in Food. In 21 CFR 182; Code of Federal Regulations; USA Federal Government: Washington, DC, USA, 2019.

28. Martins, C.D.L.; Ramlov, F.; Carneiro, N.P.N.; Gestinari, L.M.; Santos, B.F.; Bento, L.M.; Lhullier, C.; Gouvea, L.; Bastos, E.; Horta, P.A.; et al. Antioxidant properties and total phenolic contents of some tropical seaweeds of the Brazilian coast. J. App. Phycol. 2013, 25, 1179-1187. [CrossRef]

29. Lopes, G.; Clarinha, D.; Vasconcelos, V. Carotenoids from Cyanobacteria: A Biotechnological Approach for the Topical Treatment of Psoriasis. Microorganisms 2020, 8, 302. [CrossRef]

30. Lakatos, M.; Bilger, W.; Büdel, B. Carotenoid composition of terrestrial cyanobacteria: Response to natural light conditions in open rock habitats in Venezuela. Eur. J. Phycol. 2001, 36, 367-375. [CrossRef]

31. Palinska, K.A.; Deventer, B.; Hariri, K.; Lotocka, M. A taxonomic study on Phormidium-group (cyanobacteria) based on morphology, pigments, RAPD molecular markers and RFLP analysis of the 16S rRNA gene fragment. Fottea 2011, 11, 41-55. [CrossRef]

32. Rodriguez-Garcia, I.; Guil-Guerrero, J.L. Evaluation of the antioxidant activity of three microalgal species for use as dietary supplements and in the preservation of foods. Food Chem. 2008, 108, 1023-1026. [CrossRef]

33. Aydaş, S.B.; Ozturk, S.; Aslım, B. Phenylalanine ammonia lyase (PAL) enzyme activity and antioxidant properties of some cyanobacteria isolates. Food Chem. 2013, 136, 164-169. [CrossRef]

34. Latifi, A.; Ruiz, M.; Zhang, C.C. Oxidative stress in cyanobacteria. FEMS Microbiol. Rev. 2009, 3, $258-278$. [CrossRef] [PubMed]

35. Ručová, D.; Goga, M.; Matik, M.; Bačkor, M. Adaptations of cyanobacterium Nostoc commune to environmental stress: Comparison of morphological and physiological markers between European and Antarctic populations after rehydration. Czech Polar Rep. 2018, 8, 84-93. [CrossRef] 
36. Bian, Y.Y.; Guo, J.; Majeed, H.; Zhu, K.-X.; Guo, X.-N.; Peng, W.; Zhou, H.-M. Ferulic acid renders protection to HEK293 cells against oxidative damage and apoptosis induced by hydrogen peroxide. In Vitro Cell. Dev. Biol. Anim. 2015, 51, 722-729. [CrossRef] [PubMed]

37. Grauzdyte, D.; Pukalskas, A.; Viranaicken, W.; El Kalamouni, C.; Venskutonis, P.R. Protective effects of Phyllanthus phillyreifolius extracts against hydrogen peroxide induced oxidative stress in HEK293 cells. PLoS ONE 2018, 13, e0207672. [CrossRef] [PubMed]

38. Badr, O.A.M.; EL-Shawaf, I.I.S.; El-Garhy, H.A.S.; Moustafa, M.M.A.; Ahmed-Farid, O.A. The potent therapeutic effect of novel cyanobacterial isolates against oxidative stress damage in redox rats. J. Appl. Microbiol. 2019, 126, 1278-1289. [CrossRef]

39. Skulberg, R.; Skulberg, O.M. Forskning med algekulturer NIVAs kultursampling av alger. In Research with Algal Cultures; NIVA's Culture Collection of Algae; Norsk Institutt for Vannforskning: Oslo, Norway, 1990.

40. Le Gresley, M.; McDermott, G. Counting chamber methods for quantitative phytoplankton analysis haemocytometer, Palmer-Maloney cell and Sedgewick-Rafter cell. In Microscopic and Molecular Methods for Quantitative Phytoplankton Analyses; Karlson, B., Cusack, C., Bresnan, E., Eds.; IOC/UNESCO: Paris, France, 2010; pp. 25-27.

41. Andrade, M.A.; Sanches-Silva, A.; Bonito, M.C.C.; Saraiva, M.; Ribeiro-Santos, R. Characterization of rosemary and thyme extracts for incorporation into a whey protein-based film. LWT Food Sci. Technol. 2018, 92, 497-508. [CrossRef]

42. Kuskoski, E.M.; Asuero, A.G.; Morales, M.T.; Fett, R. Frutos tropicais silvestres e polpas de frutas congeladas: Atividade antioxidante, polifenóis e antocianinas. Ciência Rural 2006, 36, 1283-1287. [CrossRef]

43. Erkan, N.; Ayranci, G.; Ayranci, E. Antioxidant activities of rosemary (Rosmarinus Officinalis L.) extract, blackseed (Nigella sativa L.) essential oil, carnosic acid, rosmarinic acid and sesamol. Food Chem. 2008, 110, 76-82. [CrossRef]

44. Yoo, K.M.; Lee, C.H.; Lee, H.; Moon, B.; Lee, C.Y. Relative antioxidant and cytoprotective activities of common herbs. Food Chem. 2008, 106, 929-936. [CrossRef]

45. Strober, W. Trypan Blue Exclusion Test of Cell Viability. Curr. Protoc. Immunol. 2001, 21, A-3B. [CrossRef]

46. Mosmann, T. Rapid colorimetric assay for cellular growth and survival: Application to proliferation and cytotoxicity assays. J. Immunol. Methods 1983, 65, 55-63. [CrossRef]

(C) 2020 by the authors. Licensee MDPI, Basel, Switzerland. This article is an open access article distributed under the terms and conditions of the Creative Commons Attribution (CC BY) license (http://creativecommons.org/licenses/by/4.0/). 